\title{
AC 2011-2382: ENGAGING UNDERREPRESENTED MIDDLE SCHOOL STUDENTS IN ENGINEERING AND SCIENCE THROUGH A TWO-DAY SUMMER CAMP
}

Jessica Alvarenga, California State University, Los Angeles

Mark Vincent Abbott, CSULA

Alexander Abramyan

Jianyu Dong, California State University, Los Angeles

Mr. Oleg Gontar

Huiping Guo, California State University, Los Angeles

Eun-Young Kang, California State University, Los Angeles

Associate Professor Computer Science California State University, Los Angeles

Mr. Victor Mejia

Phanit Pollavith, CSULA

Ricardo Sanchez

Jose Antonio Zamalloa

Nancy Warter-Perez, California State University, Los Angeles

Nancy Warter-Perez is a Professor of Electrical and Computer Engineering at California State University, Los Angeles and the Director of the IMPACT LA NSF GK-12 Program. 


\section{Engaging Underrepresented Middle School Students in Engineering and Science through a Two-day Summer Camp}

\section{Introduction}

Summertime is a time when students have an opportunity to take a three month break from school. Most middle school kids participate in summer programs, camps and other recreational activities. The IMPACT LA (Improving Minority Partnership and Access through Computer, Information Science, and Engineering-related Teaching) Summer Camp allows middle school kids to be scientists and engineers for two days and to interact with graduate students on a college campus. In addition, the summer camp provides graduate fellows an opportunity to practice conducting activities with kids and communicating science and engineering to a broader audience. IMPACT LA is a National Science Foundation (NSF) Graduate STEM Fellows in K-12 Education (GK12) Program that partners graduate fellows conducting master's research in engineering and science with math and science middle and high school teachers in the East Los Angeles (East LA) area. ${ }^{1}$ During the year, the graduate fellows are visiting scientists and engineers, bringing their research into the classroom. The summer camp is the culmination of the summer workshops that are conducted to train graduate fellows and their partner teachers.

This paper provides an overview of the IMPACT LA Program including a brief description of the graduate fellows' research and the community demographics of students impacted by the IMPACT LA Program. Following this, the various individual fellow-led and group summer camp activities will be described. At the end of the summer camp, the student participants, the graduate fellows and their partner teachers were asked to complete surveys on their experience. The results on the effectiveness of the summer camp on helping to prepare the fellow for the classroom and the impact of the camp on the middle school kids will be presented.

\section{Program overview}

The IMPACT LA Program partners graduate teaching fellows with middle and high school math and science teachers in the Los Angeles Unified School District (LAUSD). The program is centered at California State University, Los Angeles (CSULA), and is part of the NSF GK12 Program, which provides fellowships and training for graduate students in science, technology, engineering, and mathematics (STEM). The graduate student fellows serve as visiting scientists or engineers who work closely with their partner teachers to engage middle and high school students in science and engineering demonstrations, presentations, and activities related to the fellows' research.

The two primary goals of the IMPACT LA Program are to 1) change teachers, students, and parents' perceptions of engineers and encourage K-12 students to explore engineering and research careers, and 2) to enhance the communication and research skills of graduate fellows. To achieve these goals, during workshops teachers participate in a wide range of research experiences designed by fellows to introduce and update teachers to their research areas. Graduate fellows conduct Master's thesis research in Computer Science, Computer/Electrical Engineering, Bioinformatics, Biomedical Engineering, Mechanical Engineering, Civil 
Engineering, Biology, Chemistry, Physics, and Math. CSULA faculty train fellows through a preparation course and workshops in order to improve communication, collaboration, and teaching skills. Furthermore, a strong partnership between CSULA, LAUSD, local industry, and minority serving organizations such as Great Minds in STEM and MESA has been established in order to achieve program goals.

Broader impacts of the IMPACT LA Program include increasing the number of underrepresented minority students who pursue college degrees and careers in STEM and to strengthen the research and teaching skills of the graduate fellows. The IMPACT LA Open House brings students from the fellow's classroom to campus to see their fellow's research lab, visit other research labs, conduct fun science and engineering activities, and learn more about science and engineering careers and educational opportunities. The IMPACT LA Summer Camp outreaches to kids in the CSULA community in order to have a greater impact on more kids.

\section{Summer camp objective}

IMPACT LA organized a summer camp for a second year to promote science and engineering in underrepresented communities. Middle school kids are exposed to fun and engaging activities while learning about STEM related concepts behind them. An increase in awareness and interest in STEM related subjects is expected to be obtained from kids at the end of summer camp. Attending parents will witness how kids' exposure to graduate fellows can increase their interest for STEM related fields and may have an impact on their outlook towards higher education.

Another goal of the camp, which is the culmination of the summer training workshops, is to provide teaching graduate fellows an opportunity to interact with middle school students. At the end of summer camp fellows gain experience in understanding and engaging students in order to prepare for the upcoming school year. This past year partner teachers were included as part of the camp in order to help foster a strong partnership between the fellow and teacher. The teachers assisted the fellows during activities and provided them with valuable insights on classroom management, techniques for engaging students, suggestions on age-appropriate communication/vocabulary, and suggestions on how to scale the activity if time was too short or if there was extra time.

\section{Community demographics}

The IMPACT LA summer camp seeks to reach out to middle school students in the East LA area as well as areas surrounding the CSULA campus. CSULA is largely a commuter school with many areas of study. Table 1 highlights some of the undergraduate student characteristic data for undergraduate enrollment in the fall quarter of $2009 .^{2}$ About $60 \%$ of the undergraduate population at the time was $60 \%$ women and $40 \%$ men. The largest percentage of students was of Hispanic origin (48\%), with the second largest group being of Asian or Pacific Islander decent (19\%).

Table 2 shows the demographics for the surrounding communities of CSULA in comparison with demographics for the United States on average. The surrounding communities include El Sereno, Boyle Heights, and East LA, among others, all of which comprise of largely Hispanic population. Also neighboring CSULA are Alhambra and Monterey Park, comprised 
largely of an Asian and Pacific Islander community. Students in the neighboring communities are often the first generation in their family to attend college.

Table 1. CSULA Demographics Fall 2009. ${ }^{2}$
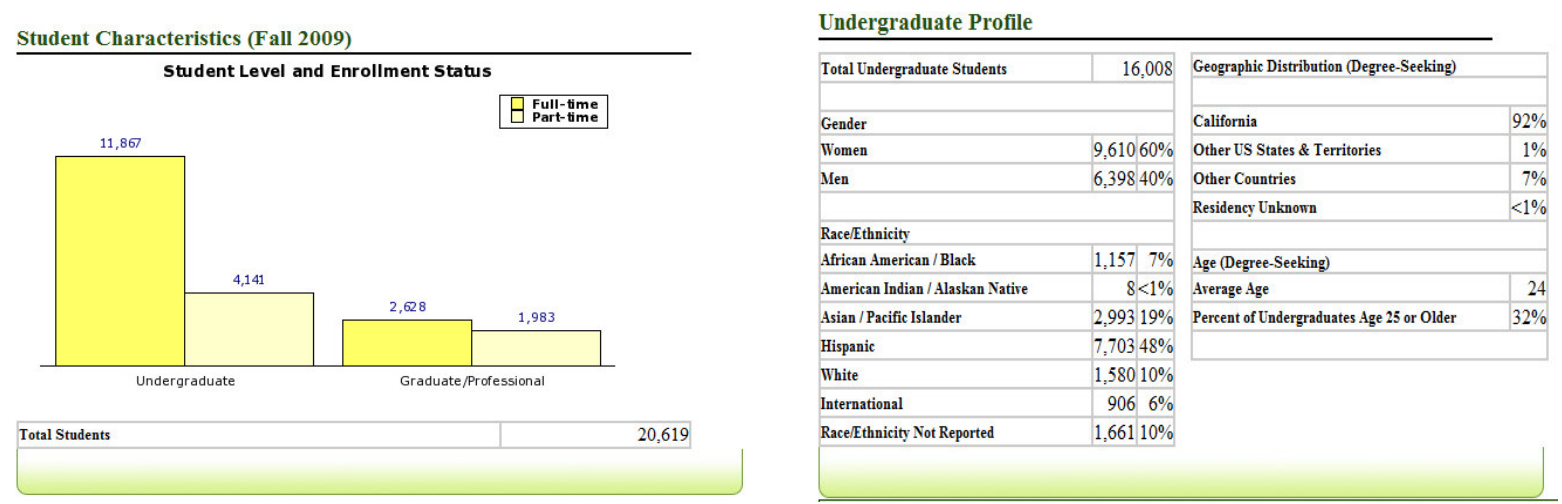

Table 2: CSULA Community Demographics (source: US Census Data by Zip Code for 2000 http://factfinder.census.gov). Zip codes included for CSULA Community are 90022, 90023, 90031, 90032, 90033, 90042 90063, 91030, 91754, 91801, and 91803.

\begin{tabular}{|l|c|c|}
\hline Selected Demographic Information & Average for CSULA Community & U.S. \\
\hline Hispanic & $65.66 \%$ & $12.5 \%$ \\
\hline Asian & $21.35 \%$ & $3.6 \%$ \\
\hline High school graduate or higher & $52.92 \%$ & $80.4 \%$ \\
\hline Bachelor's degree or higher & $16.95 \%$ & $24.4 \%$ \\
\hline Median family income in 1999 & $\$ 37,473$ & $\$ 50,046$ \\
\hline Families below poverty level & $19.65 \%$ & $9.2 \%$ \\
\hline
\end{tabular}

\section{Fellow backgrounds and majors of study}

For the 2010-11 academic year, there are eight fellows in the IMPACT LA program, each paired with a teacher from a local high school or middle school for the year. These fellows are conducting research towards a Master's thesis in the fields of science and engineering. Table 3 lists the fellows, their major, their partner teacher and school subject. These same teachers work with the fellow to aid in the summer camp. Short descriptions of each fellow's research are also provided.

\section{Fellow Research Topics}

Mark Abbott: Improving efficiency of residential vertical axis wind turbines by directing airflow and using sophisticated control methods to affect power output.

Jessica Alvarenga: Conducting research at the NASA URC SPACE Center focusing on developing control algorithms for large scale space structures. 
Oleg Gontar: Conducting research on the effects of a jojoba oil diet on the reverse cholesterol transport in New Zealand White rabbits.

Victor Mejia: Developing an object tracking algorithm for real-time automated video analysis in the presence of occlusions.

Omar Miranda: Studying the effectiveness of ultra violet lighting on greywater purification.

Phanit Pollavith: Developing a fragile watermarking scheme that detects and localizes illegal modifications for digital images/video. The main part of his research will involve developing watermarking software that visualizes the watermarking embedding and detection process.

Ricardo Sanchez: Creating a computer program that predicts the oxidation susceptibility of protein cysteine thiols using protein structural data.

Jose Zamalloa: Studying cancer prevention protein leading to a better understanding of metal toxicology effect on human proteins.

Table 3: Fellow and Teacher information.

\begin{tabular}{|c|c|c|c|c|}
\hline $\begin{array}{l}\text { Fellow } \\
\text { Name }\end{array}$ & Major & Teacher Name & School & Subject \\
\hline $\begin{array}{l}\text { Mark } \\
\text { Abbot }\end{array}$ & $\begin{array}{c}\text { Electrical } \\
\text { Engineering }\end{array}$ & Jorge Reyes & $\begin{array}{c}\text { Hollenbeck } \\
\text { Middle School }\end{array}$ & Pre-algebra \\
\hline $\begin{array}{c}\text { Jessica } \\
\text { Alvarenga }\end{array}$ & $\begin{array}{c}\text { Electrical } \\
\text { Engineering }\end{array}$ & Israel Hernandez & $\begin{array}{c}\text { Roosevelt High } \\
\text { School }\end{array}$ & $\begin{array}{c}\text { Algebra } 2 \text { and } \\
\text { Geometry }\end{array}$ \\
\hline $\begin{array}{l}\text { Oleg } \\
\text { Gontar }\end{array}$ & Biology & $\begin{array}{l}\text { Tony Semaan and } \\
\text { Christine Rosser }\end{array}$ & $\begin{array}{c}\text { Hollenbeck } \\
\text { Middle School }\end{array}$ & $7^{\text {th }}$ Grade Life Science \\
\hline $\begin{array}{l}\text { Victor } \\
\text { Mejia }\end{array}$ & Computer Science & Gabriel Trejo & $\begin{array}{c}\text { Roosevelt High } \\
\text { School }\end{array}$ & $\begin{array}{c}\text { Algebra } 2 \text { and } \\
\text { Geometry }\end{array}$ \\
\hline $\begin{array}{c}\text { Omar } \\
\text { Miranda }\end{array}$ & $\begin{array}{l}\text { Mechanical } \\
\text { Engineering }\end{array}$ & Cynthia Godoy & $\begin{array}{c}\text { Stevenson Middle } \\
\text { School }\end{array}$ & $\begin{array}{l}6^{\text {th }} \text { Grade Earth } \\
\text { Science }\end{array}$ \\
\hline $\begin{array}{c}\text { Phanit } \\
\text { Pollavith }\end{array}$ & Computer Science & Adriana Trejo & $\begin{array}{l}\text { Roosevelt High } \\
\text { School }\end{array}$ & $\begin{array}{c}\text { Algebra 1, } \\
\text { Trigonometry, Math } \\
\text { Analysis and AP Stats }\end{array}$ \\
\hline $\begin{array}{l}\text { Ricardo } \\
\text { Sanchez }\end{array}$ & Biochemistry & Brianna Rojas & $\begin{array}{c}\text { Stevenson Middle } \\
\text { School }\end{array}$ & $\begin{array}{c}\text { 8th Grade Physical } \\
\text { Science }\end{array}$ \\
\hline $\begin{array}{c}\text { Jose } \\
\text { Zamalloa }\end{array}$ & Biochemistry & John Cerezo & $\begin{array}{c}\text { Stevenson Middle } \\
\text { School }\end{array}$ & $7^{\text {th }}$ Grade Life Science \\
\hline
\end{tabular}




\section{Camp activities}

The activities that summer camp attendees participated in can be broken into two categories: individual fellow led activities and group activities. For the individual fellow led activities, the students were separated into smaller groups, each led by a fellow-teacher pair. These fellow-teacher pairs guided their group of about 20 students from activity to activity. For the group activities, one to three fellows designed and conducted the activity for the entire group of summer camp participants. These activities were conducted at the beginning of the day, during lunch, and at the end of the day when the smaller groups were able to reconvene.

\section{Individual fellow-led activities}

For the individual fellow-led activities, each fellow had the opportunity to lead an activity for a smaller group of approximately 20 students. The individual fellow-led activities allowed the fellows to experience a classroom environment, have an opportunity to teach kids a science or engineering concept, and to conduct a hands-on activity. Assisted by their partner-teacher, fellows gained valuable insight into what to expect when they entered their classroom in the fall. Kids also had an opportunity to learn in more depth eight different areas of engineering, computer science, and science.

Soda Can Shake $\mathbf{U p}^{\mathbf{3}}$ : In this activity, students explore how to prevent a soda can from exploding. Shaking an unopened can of soda increases the number of carbon dioxide bubbles lining on the inside walls of the can. When you open the can, the pressure in the can goes down and the volume of each bubble goes up. The quickly expanding bubbles force the liquid that rests above it out of the can. When you hit the can from each side you get rid of these bubbles lining on the inside walls of the can. As a result, the bubbles that were lining on the sides on the can float to the top of the can. This will prevent a soda can from exploding. Figure 1 shows the activity using baby bottles to allow students to see what is going on inside.
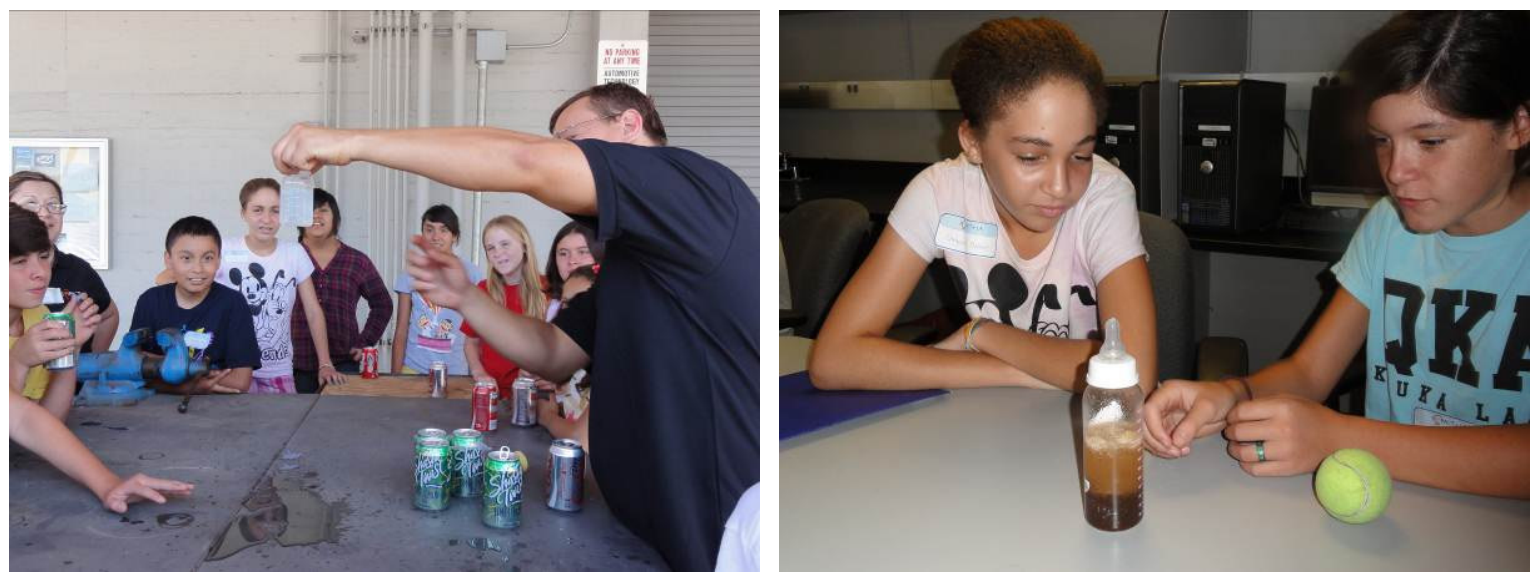

Figure 1. Fellow demonstrating the Soda Can Shake Up (Left). Students performing activity (Right).

Popsicle Tower: In this activity, summer camp students were tasked to construct a small rectangular/square structure that would be able to support their weight as shown in Figure 2. For those structures that were able to support their weight the final test was to test the structure to see if it would withstand the fellow's weight. The students were advised to sketch their designs prior 
to constructing them so they would be more likely to build a structure that would survive the weight test.
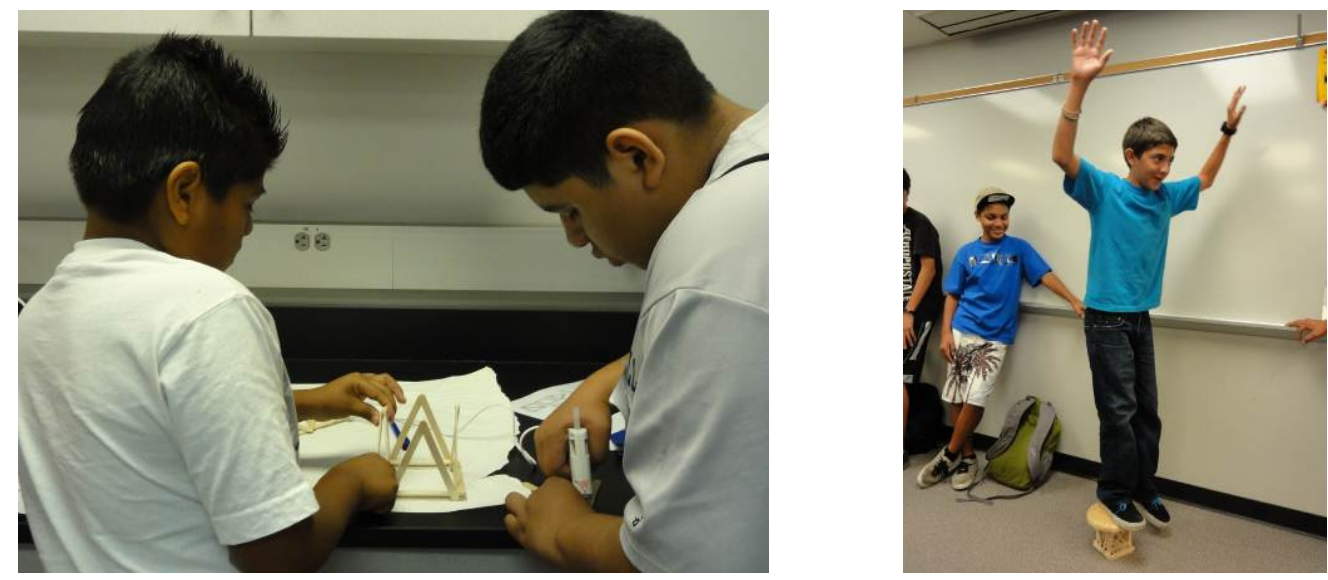

Figure 2. Students beginning construction (right). Testing the strength of their tower (left).

Electric Motor ${ }^{4}$ : In this activity, kids were able to build a simple DC motor using household items as shown in Figure 3. Using a D-cell battery, a rubber band, paper clips, a magnet and some magnetic wire, the kids were all able to build their own motors. When current passes through the magnetic wire, an electromagnet is created. This interacts with the permanent magnet and causes rotation. The children were able to learn about the basics of every electric motor and learn that magnets can be created from electricity.
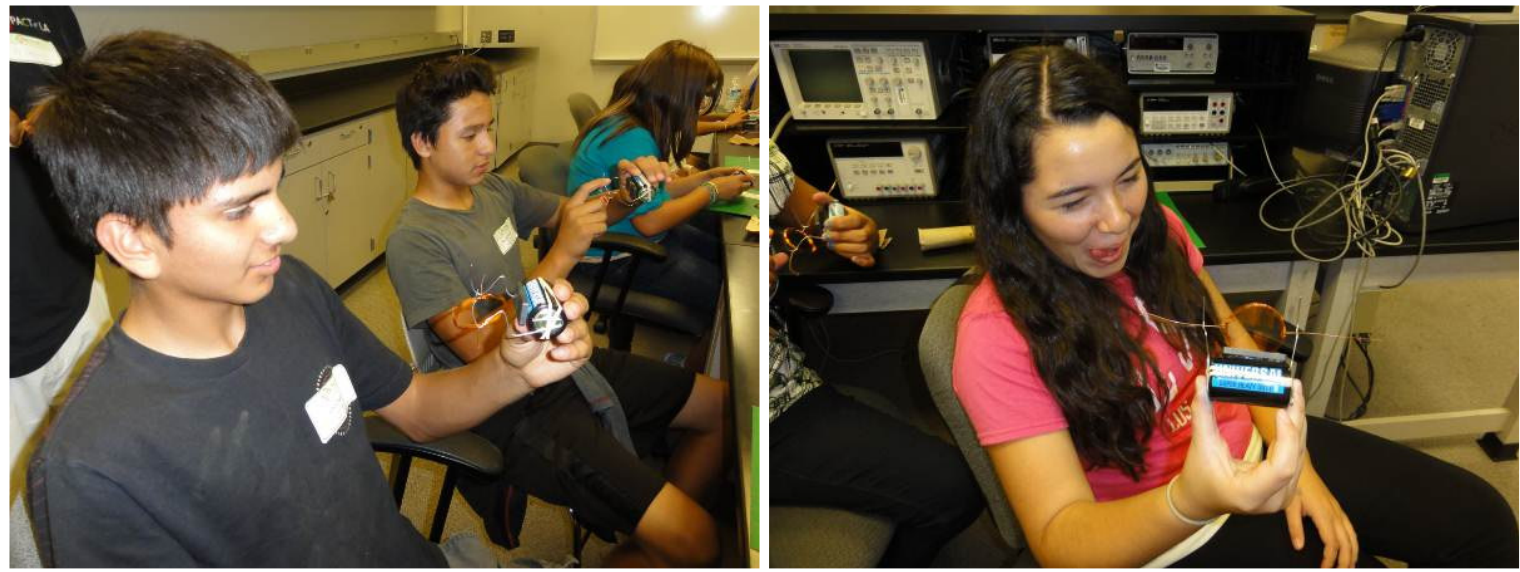

Figure 3. Students working on Electric Motor

Scytale Messages $^{5}$ : In this activity, kids write and decode secret messages as shown in Figure 4. This activity requires scissors, paper, scotch tape, and various types of cylinders with different size diameters such as paper towel tubes, soda bottles, and soda cans. By wrapping paper ribbon around the cylinders, students can then write their secret message. When the ribbon is removed, the message becomes encrypted. Only by rewrapping the ribbon onto the appropriately sized cylindrical object will the message become known. This shows kids how secrets may have been sent and decoded before times of the internet and telephones. 

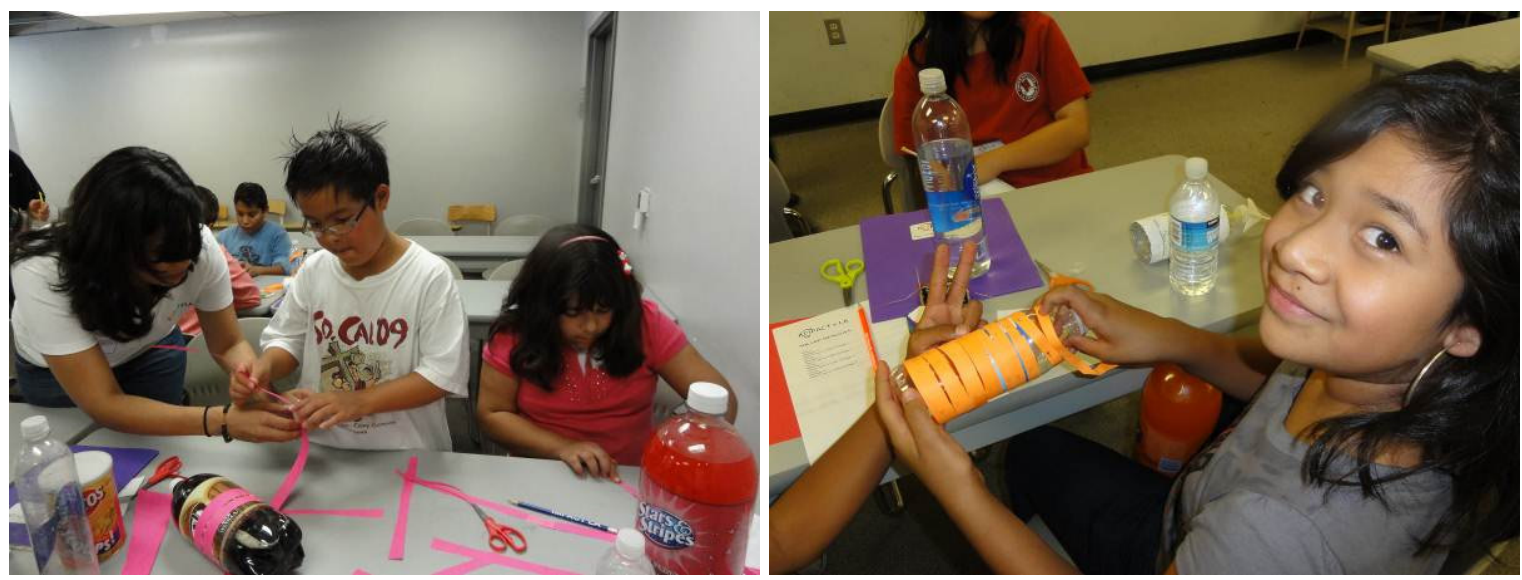

Figure 4. Scytail Messages

Paper Towel Chromatography: Students in the summer camp also participated in a Crime Scene Investigation (CSI) style lab dealing with ink chromatography. A fake crime scene was set up in which the "criminal" left a note marked with black ink. A fun and comical video was shown to the students indicating that there were four different suspects, and each one had a favorite pen. The goal was to match the ink with the corresponding pen of the suspect. Students were asked to think about how they could solve this problem. Students were then placed into groups of four, and each student obtained a copy of one of the suspect's pen. As they dived into the crime lab with their latex gloves, each student had to perform the process of ink chromatography using either water or alcohol to see the composition of the different inks. The groups performed the chromatography on the note left at the crime scene and were able to match the pen and identify the "criminal" as shown in Figure 5.
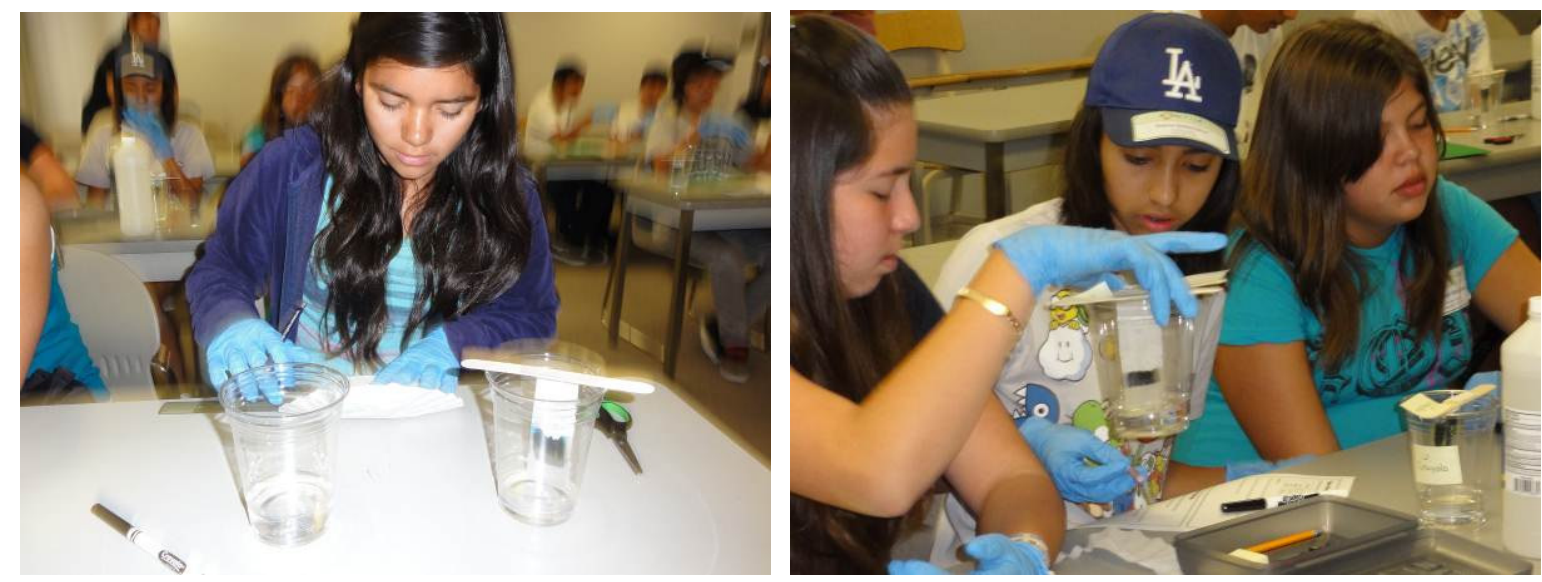

Figure 5. CSI Paper Towel Chromatography

Rainbow Scope: In this activity, students explore the properties of light. Unlike paint, the primary colors of light are red, green and blue. However, similar to mixing paint, mixing different colors of light will create a new color. In this activity, students built spectroscopes with everyday materials. Pieces of CDs, like those used to listen to music or to store data, are used to split the light spectrum. Students use their CD spectroscopes to view the spectrums of various 
colors of Light Emitting Diodes (LEDs) as shown in Figure 6. When viewing the different colors of light, they are able to see the spectrum of that particular LED.
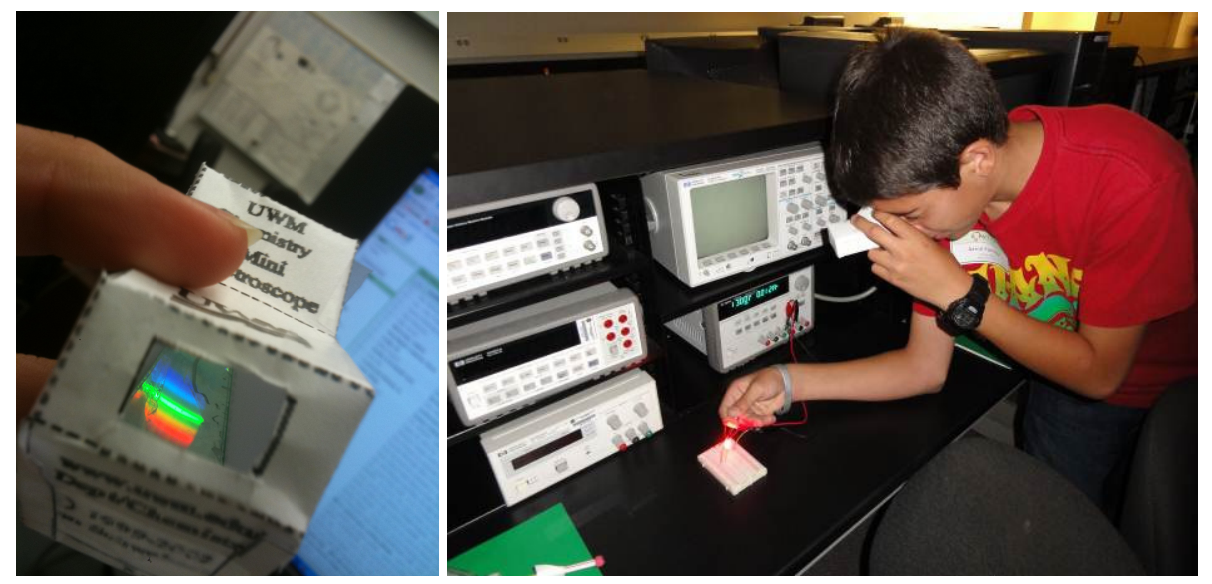

Figure 6. View of spectroscope (Left). Students testing their spectroscopes (Right).

Plastic Milk ${ }^{6}$ : Kids learn about gravity, electricity and chemicals in their science classes. During the plastic milk activity kids learn that science can also be found right in their kitchens. In this activity they mix the acid found in vinegar and the proteins present in milk to activate a chemical reaction. They learn that much like cottage cheese and yogurt, the proteins in milk need to be activated in order to take certain shape and change in chemical properties. At the end of this fun activity they are able to shape their "plastic milk" and take home a scientific souvenir. Figure 7 shows students creating their mixtures and some resulting sculptures.
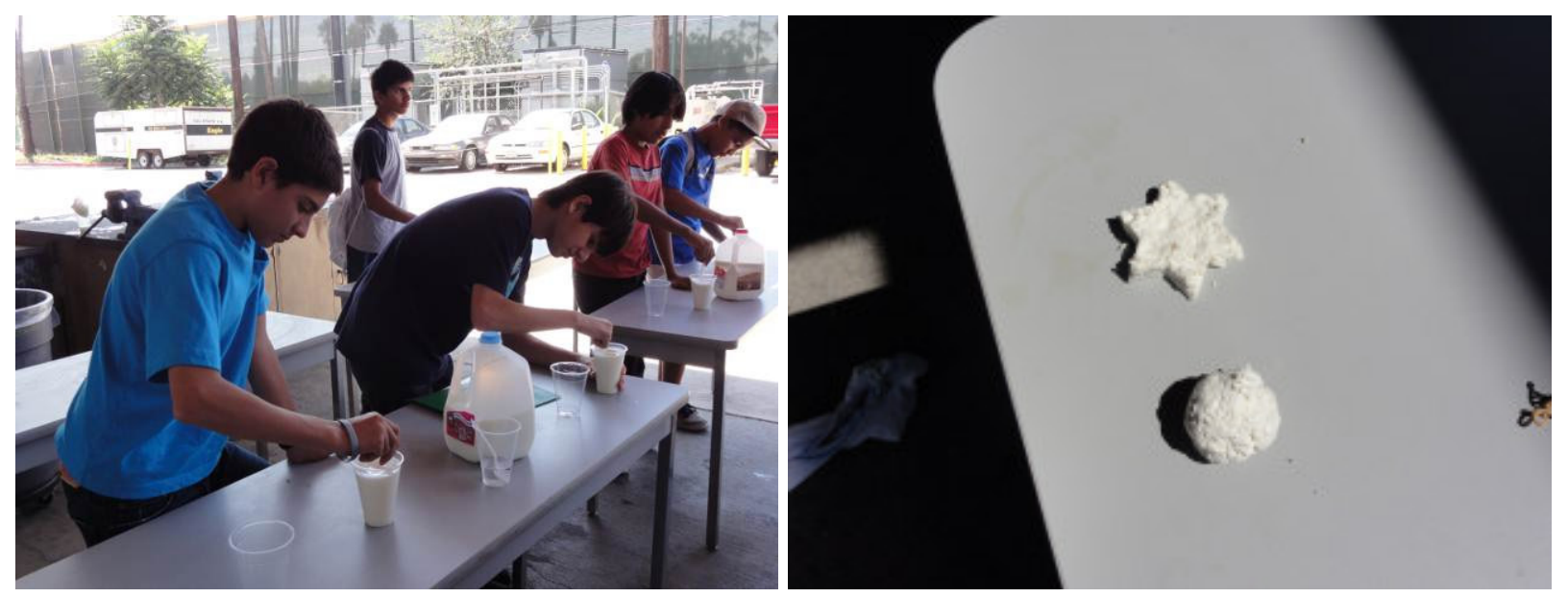

Figure 7. Kids look at the result of their chemical reaction after mixing vinegar and milk (Left). The creative results of their hard work need to dry under sun before they can take it home (Right).

Sweet Rides: Camp participants got to make a self-propelled toy car with straws, craft sticks, balloons, rubber bands, and Lifesavers candy for tires. The purpose of the activity was for the kids to learn about potential and kinetic energy. To make the cars run, the kids inflated the 
balloon attached to their car, which stored potential energy in the car. When the kids released the air from their car, the potential energy gets converted into kinetic energy making the car take off as shown in Figure 8. The fun came when the kids raced their car with other participants and when they got to eat their spare tires.
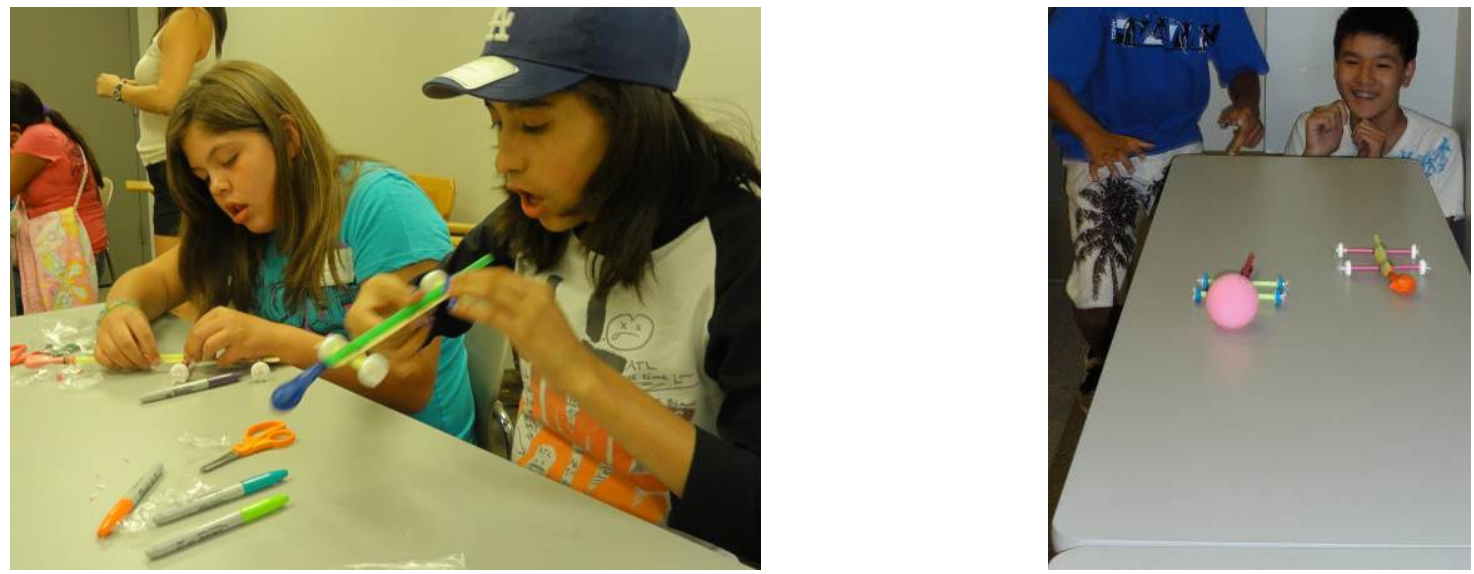

Figure 8: Students constructing (left) and racing (right) their "Sweet Rides".

\section{Group activities}

During the summer camp, fellows conducted group activities with the kids. Some activities, such as Smokin' Hot Cheetos, super cooling water demonstration, bottle rockets, and the finger printing CSI activity, were designed to engage the kids in fun activities and get them excited about the different fields of engineering and science. Two design challenges, a cardboard boat race and an egg drop challenge, were offered to foster creativity and collaboration and enhance leadership skills among students.

Boat Race: Kids had to become engineers in order to compete against others in a boat design competition. This activity challenged their creativity and fostered teamwork among group members as shown in Figure 9. They were supplied with materials including cardboard, tape and plastic bags in order to design a boat that could float and help them get across the pool. Students had fun racing against each other as shown in Figure 10.

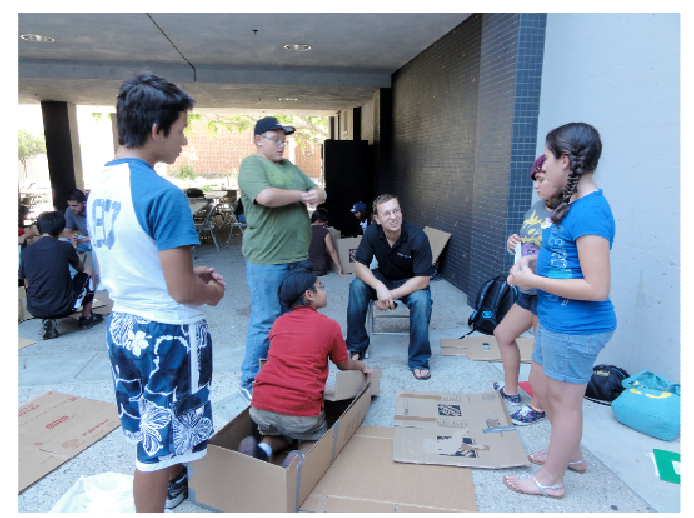

Figure 9. Students discuss how to better use materials provided while graduate fellow provides support. 


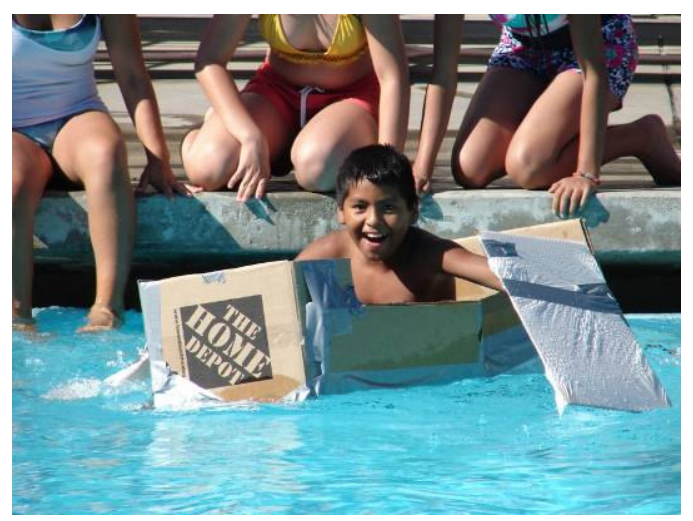

Figure 10. Students' innovative and creative boat design is tested on water.

Smokin' Hot Cheetos: Fellows demonstrate the nature of subzero temperatures in a unique and edible way by using Cheetos as shown in Figure 11. Liquid nitrogen is capable of freezing the surface of materials that comes in contact with. It is used in many aspects of research to keep samples fresh and stored for a long period of time. Liquid nitrogen is stored in special containers keeping it in a liquid state. However, it becomes gas once it is exposed to the atmosphere. Kids learned about the nature of liquid nitrogen witnessing how it interacts with a popular snack and, as shown in Figure 12, they were able to play with blowing smoke signals arising from the nitrogen-chilled Cheetos as the kids ate them.

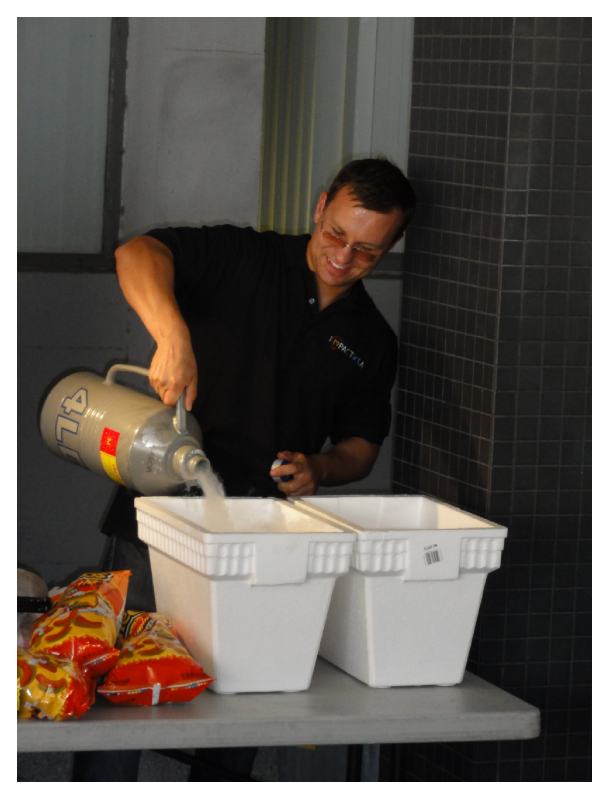

Figure 11. Cheetos freeze upon contact with liquid nitrogen, poured by graduate fellow.

Egg Drop: Kids participated in groups in an Egg Drop competition to challenge their engineering skills. They had to design an egg container that would resist free fall while keeping eggs intact and landing on a target (Figures 13 and 14). They were provided with materials including egg cartons, bubble wrap, tape, packaging peanuts and plastic cups. Kids were rewarded for their efforts based on creativity, design and successful attempts. New this year, 
kids were given a budget and had to "purchase" materials using IMPACT LA dollars. Students learned about cost-performance trade-offs.

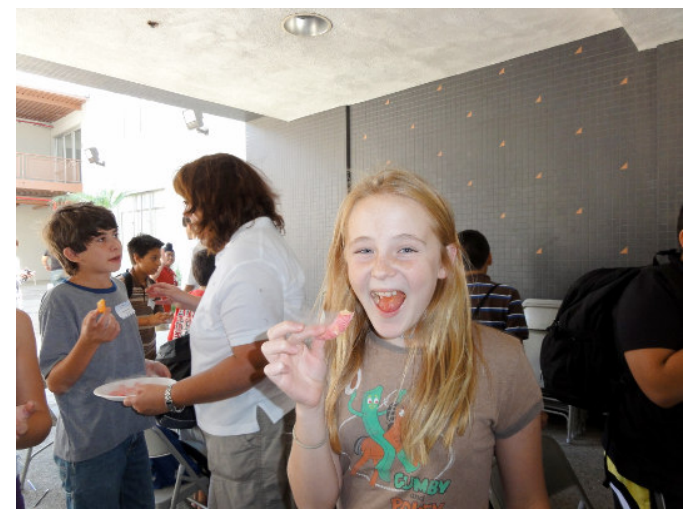

Figure 12. Kids can observe, taste cool snacks and blow smoke signals.

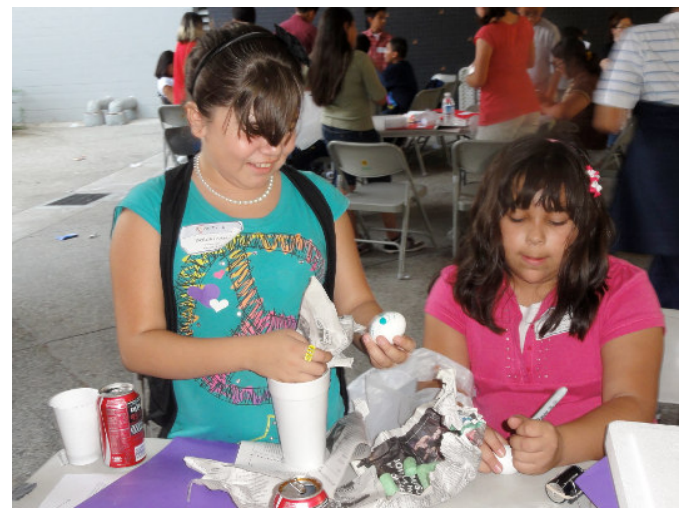

Figure 13. Kids engineer an innovative way to make their egg survive.

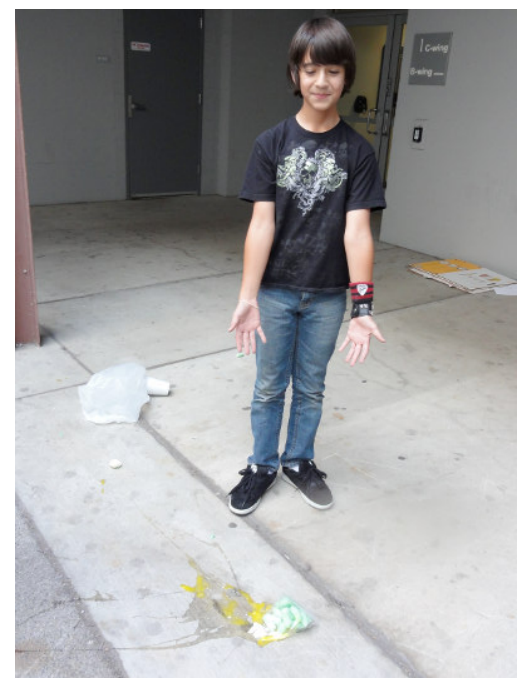

Figure 14. Kids learn that more than one attempt may be needed for successful results. 
Supercool water: Most kids know that liquid water becomes ice below a certain temperature when they see snow or look at the freezer at home. Surprisingly pure water can maintain its liquid form below that temperature if kept untouched. During this interesting activity kids got to experience how liquid water instantly turns into ice as it is poured. Similar to liquid sand, it can form small ice sculptures as it pours. As shown in Figure 15, kids were fascinated by this activity and were eager to learn how to do it at home.

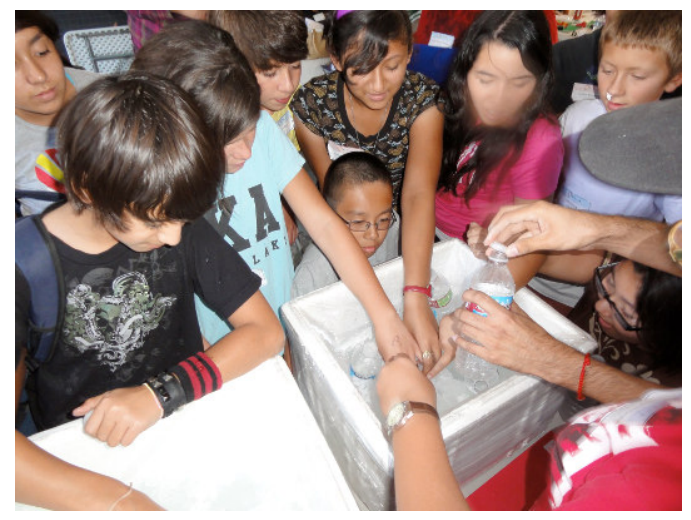

Figure 15. Kids experience water supercooling first hand as they witness instantaneous freezing of water.

Bottle Rocket: Pressure is used to move engines such as the ones present in cars and boats. Kids applied the same concept to build rockets out of water bottles and straws. They sealed pressure inside the bottles with clay and released their rockets into the air by applying external pressure with their hands. In doing this activity they were able to appreciate the mechanics of force. Figure 16 shows students working on their rockets while Figure 17 shows students launching their rockets.

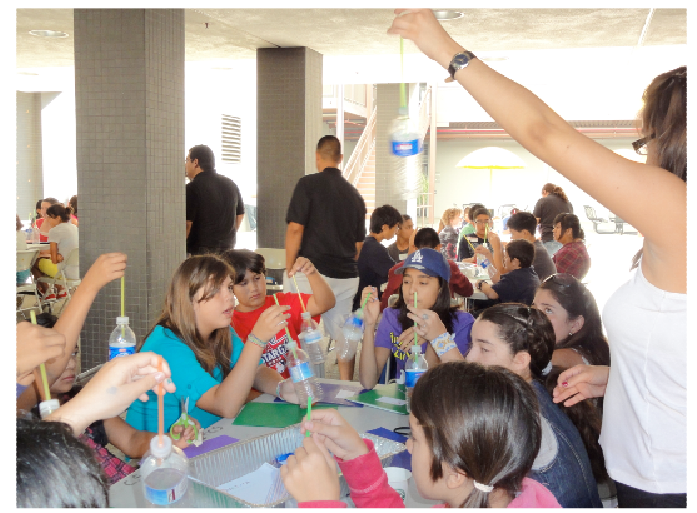

Figure 16. Kids with the help of teachers and fellows work together to build bottle rockets. 


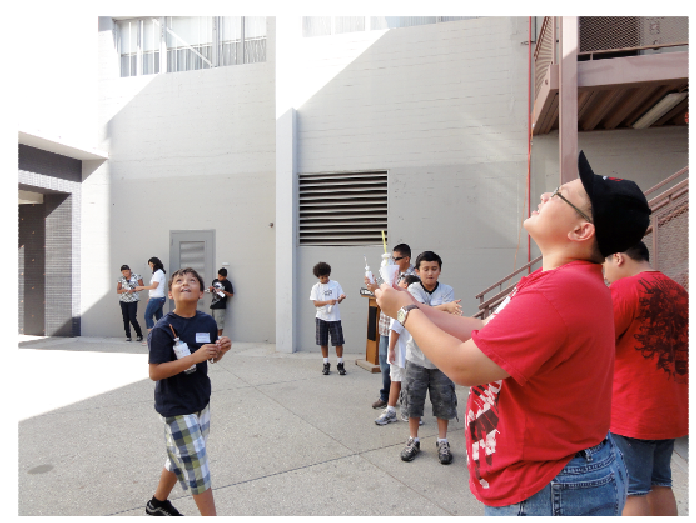

Figure 17. Kids see the result of their hard work in action when shooting their rockets into space.

Finger printing: The fingerprint activity allowed kids to explore the different types of fingerprints that people may have. Although no two sets of fingerprints are the exactly the same, the types of fingerprints may be similar. Using a pencil, paper, and tape, kids were able to fingerprint themselves using the pencil lead as ink and compare their fingerprints to the handout to find their type or classification as shown in Figure 18. At the end of this activity, kids were asked to find at least two other students with the same type of fingerprints as themselves. This ice-breaking activity at the beginning of the camp day allowed kids to socialize with other kids while learning about the different types of fingerprints.
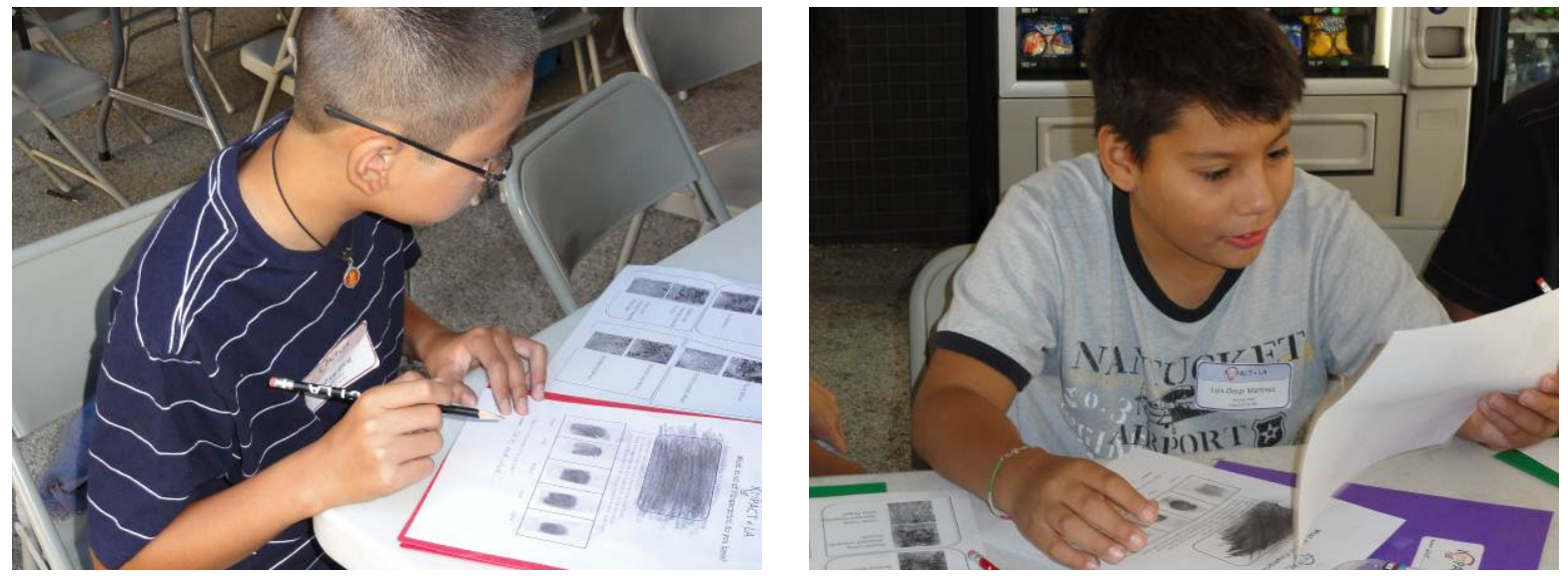

Figure 18. Students working on the fingerprinting activity.

\section{Impact on kids}

A total of 62 students attended the summer camp in August of 2010 and completed the summer camp assessments. Students were asked to select their two favorite group activities, from a total of six. Figure 19 shows that the boat race was selected the most favorite group activity with a total of 38 tallies, followed by the Smokin' Hot Cheetos (32) and the egg drop (25). The two design challenges ranked high most likely because students got to be creative, have fun working with others, and compete to see if their engineering design was the best.

Students were judged on many categories such as best overall design, most cost effective, fastest, most durable, most creative, etc. Students also liked to have fun with science and experience the mysteries of science in the Smokin' Hot Cheetos experiment and the Super Cool water 
experiment. Since the Super Cool only worked for one group of students due to difficulty with freezing the water to the correct temperature at the right time during lunch, students must have really enjoyed it to have it rank fourth overall.

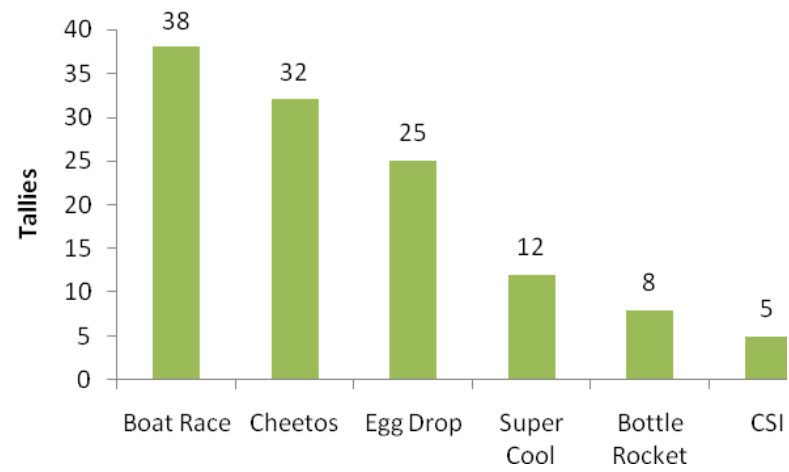

Figure 19. Students' favorite summer camp group activities.

In addition, students were asked to select their top three individual activities from the eight in which they participated. Figure 20 shows that the soda can shake-up was selected the most favorite with a total of 30 tallies, followed by popsicle stick tower (29) and electric motor (27).

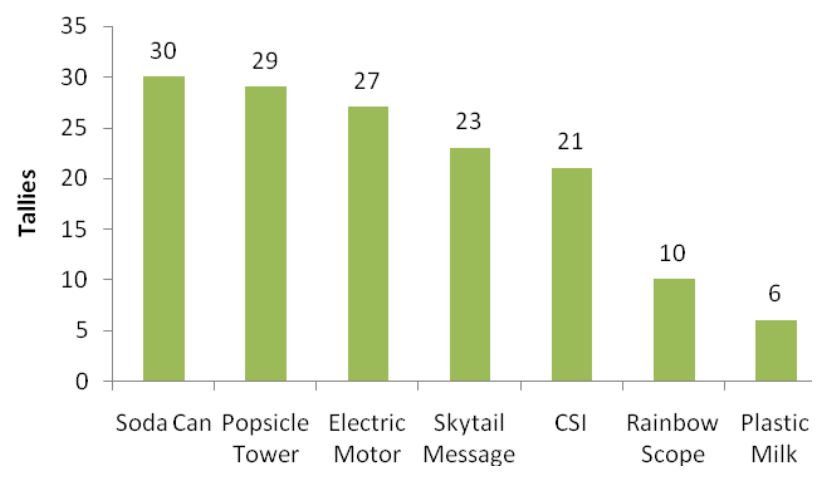

Figure 20: Student's favorite summer camp individual activities.

Also, students were asked open-response questions about what camp had thaught them about science, and whether they would like to see activites such as the ones they participated in during the camp in their classrooms. Students gave wide range of responses such as:

"I learned how liquid nitrogen affected things, and about protein and energy in our body. Also what vinegar does to milk."

"That science isn't easy but that science is what discovers what the world is about and stuff."

"It taught me that you can do a lot of stuff with science"

"About the different engineering of different variables of science, but fun."

"It taught me that a scientist predicts before doing" 
Of the 60 students who responded to the final question regarding whether they would like to see more hands-on activities in the classroom, 59 (98\%) responded "Yes." A few students gave more elaborate responses, a selection of which is given below.

"Yes I would. These activities were really fun ways to learn. I loved them."

"Yes if science was this fun at school it would be my favorite subject"

"Yes, I would like more hands on DEFINTELY"

Like other summer programs, the IMPACT LA summer camp is open to anyone in the neighboring community. This allows kids to meet, interact, socialize and work with other kids that do not go to their same schools. Many positive responses from parents were received highlighting the enjoyment their children had at the camp. Two of these responses are provided below:

“ Thank you for this wonderful Summer Camp program that was offered last week (Aug. 25-26). I wanted to take the time to provide you with a little bit of feedback. My son truly enjoyed the two days he spent at Impact LA. Not only did he enjoy the curriculum but the new friends he made. Each night, he talked about the wonderful activities he participated in and how much he enjoyed each and every one of them. As a matter of fact, he wondered why the program has to end after just two days. This has been a positive experience for him and is looking forward to the program next year (if it's offered again)!'- Parent of student attendee

"Thank you so much! My nieces are so excited about their experience and are telling me all about the boat race. You have definitely sparked in interest in them for science and engineering. They even want to recreate the boat race as the theme for my son's birthday pool party next week!! ... Thank you again. We hope you have the program again next year...we will definitely be back!!" -Aunt of two Summer Camp attendees

One of the effects of having a science and engineering summer camp at a university in the community led by students conducting research in science and engineering fields is that kids get to see people with similar backgrounds as themselves pursuing advanced degrees in the fields of science and engineering. In addition, the enthusiasm that the kids took home with them about the activities they did during the camp would then be shared and spread to their families and friends. Kids could share what they learned with others, hopefully sparking interest in STEM fields to more than the participants of the camp. One observation that was made is that many of the students that participated the first year of the summer camp came back the second year, some bringing along their friends that had not participated the first time around. The summer camp also had a broader impact on the Los Angeles community by a report and video broadcast on KLCS-58 7 .

\section{Impact on fellows/teachers}

In addition to assessing the impact of the summer camp on the middle school participants, the fellows and teachers were asked to complete assessment surveys of their 
experience and opinions of the summer camp. All questions were answered on a scale of 1 to 5 , where 1 signifies a strong disagreement with the statement and a 5 signifies a strong agreement with the statement. A response of 3 signifies a neither agreement nor disagreement with the statement.

One of the goals of the summer camp was to strengthen the relationship between the fellow-teacher partners. Another goal was to give fellows at least some experience conducting an activity before the school year began. During the camp, fellows were able to practice an activity many times and with many different groups of students. Previous to the summer camp, the fellows and teachers participate in a series of workshops allowing them to get to know each other. Fellows presented their research and teachers shared their teaching styles and conducted a simple lesson. Afterwards, fellows and teachers ranked each other and fellow-teacher pairings were determined. Previously, fellows and teachers were given only one or two days to work together before the fellow enters the classroom. By having the fellows conduct their summer camp activities in the presence of their partner teacher, the teachers were able to give fellows feedback on their presentation and activity leading ability.

Overall, fellows had a positive response to the summer camp. They felt that they were better prepared to enter the classroom, that their lesson plan delivery skills had improved, and that they had more ideas as to how to bring research into the classroom. Since the fellows acted as group guides one day and conducted their activities the other, they were given the opportunity to see some of the other fellows conducting activities. This allowed them to observe different presentation styles and delivery as well as getting ideas for activities. Figure 21 shows the average responses from the fellows to various assessment questions.

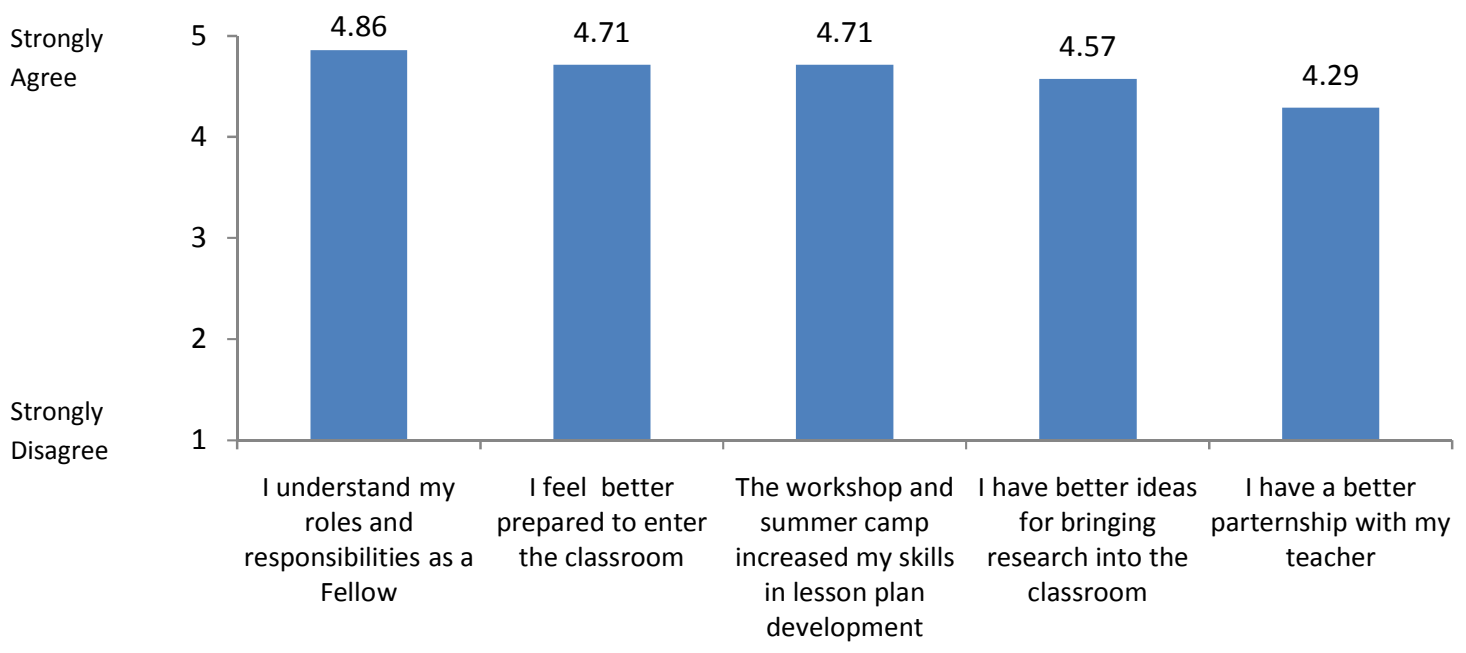

Figure 21. Fellow summer workshop and summer camp assessment responses.

As with the fellows, the teachers also had an overall positive response to the summer camp. By participating in the summer camp, teachers were able to observe the fellows as they conducted their activities. Since the fellows conducted the same activity to various groups throughout the day, teachers were able to provide feedback, give suggestions and give advice to the fellow about how they did and how to improve their next presentation. In addition, the 
teachers were able to observe various other activities that could potentially be used in the classroom. Some of the activities were enjoyed by the teachers so much that they had their fellow conduct those activities for their classes once the school year started. Figure 22 shows the average responses of teachers to various questions.

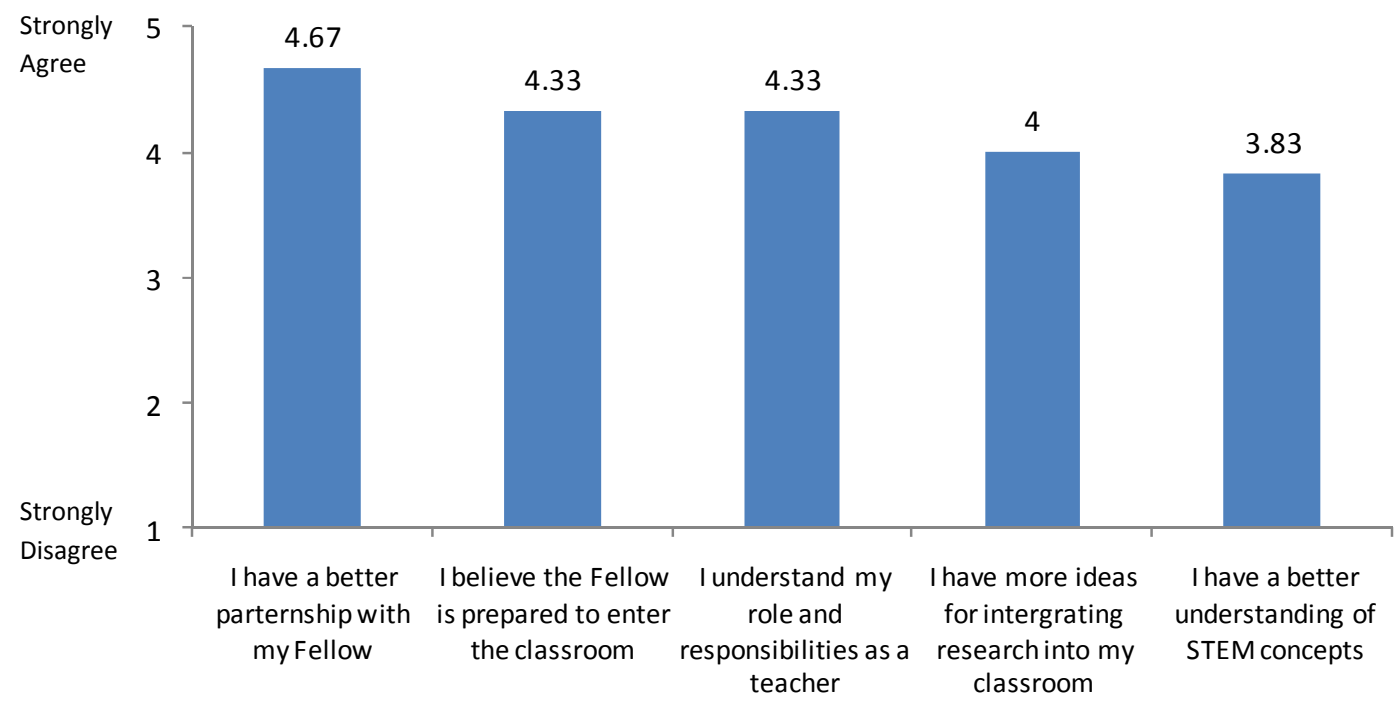

Figure 22: Teacher summer workshop and summer camp assessment responses.

\section{Conclusion}

Engineering and science summer camps have proven to be an effective outreach tool ${ }^{8-13}$. Overall, the IMPACT LA Science and Engineering Summer Camp succeeded in what was set out to be achieved. The STEM fields were promoted to middle school students from the surrounding underrepresented communities. Beyond outreach, fellows were able to successfully plan and conduct fun science and engineering related activities to groups of students. Teachers were able to observe their fellows as they conducted activities and start fostering a strong partnership. Overall, the kids, fellows and teachers had positive experiences to the camp. Lastly, kids were enthusiastic to share their experiences once they left the camp.

\section{Acknowledgement}

This work is supported by NSF Grant \#0742426.

\section{Bibliography}

[1] Warter-Perez, N., Dong, J., Kang, E., Guo, H., Castillo, M., Abramyan, A., \& Young, K., (2010). Strengthening the K-20 engineering pipeline for underrepresented minorities. Paper presented at the meeting of the American Society for Engineering Education, Louisville, KY. 
[2] California State University, Los Angeles College Portrait, College Portrait,

<www.collegeportraits.org/CA/CSULA/characteristics>. Accessed January 2011.

[3] Soda Can Shake-Up, Steve Spangler Science, <www.stevespanglerscience.com/experiment/00000024>. Accessed August 2011.

[4] Beakman's Electric Motor, <fly.hiwaay.net/ palmer/motor.html>. Accessed August 2011.

[5] Scytale Messages, PBS Kids Zoomsci, <pbskids.org/zoom/activities/sci/scytalemessages.html>. Accessed August 2011.

[6] Plastic Milk, PBS Kids Zoomsci, <pbskids.org/zoom/activities/sci/plasticmilk.html>. Accessed August 2011.

[7] KCLS-58: IMPACT LA 2010 Summer Camp, <www.youtube.com/watch?v=rthtAI7IiHw>. Accessed March 2011.

[8] Plant, A. E., Baylor, A. L., Doerr, C. E., \& Rosenberg-Kima, R. B. (2009). Changing middle-school students' attitudes and performance regarding engineering with computer-based social models. Computers and Education. 53, 209-215. Plotkowski, P., Sheline, M.A., Dill, M., \& Noble, J. (2008).

[9] Empowering girls: measuring the impact of science technology and engineering preview summer camps (STEPS). Proceedings of the 2008 American Society for Engineering Education Annual Conference \& Exposition. Pittsburgh, PA.

[10] Aung, Kendrick, and Underdown, Ryan, "Teaching Engineering to High School Students in a Summer Camp", Proceedings of ASEE Gulf-Southwest Annual Conference, March 18-20, Baylor University, 2009.

[11] Jeffers, Andrew T., Angela G. Safferman, and Steven I. Safferman. "Understanding K-12 Engineering Outreach Programs." Journal of Professional Issues in Engineering Education and Practice, April 2004.

[12] Poole, S., deGrazia, J., and Sullivan, J., “Assessing K-12 Pre-engineering Outreach Programs”, Journal of Engineering Education, 9p., Jan. 2001.

[13] Lachapelle, C. and Cunningham, C., "Engineering is Elementary: Children's Changing Understandings of Science and Engineering", Proceedings of the 2007 ASEE Annual Conference and Exposition, 33p., March $7,2007$.

[14] Yilmaz, M.; Jianhong Ren; Custer, S.; Coleman, J.; , "Hands-On Summer Camp to Attract K-12 Students to Engineering Fields," Education, IEEE Transactions on , vol.53, no.1, pp.144-151, Feb. 2010. 